\title{
El cristocentrismo de san Agustín. El período antidonatista
}

Este período es demasiado extenso y en él se producen muchos cambios profundos que se deben a múltiples influencias, por ejemplo, a una constante meditación sobre la predestinación, la gracia, el pecado original, el modo de aplicar el crede ut intelligas, la relación entre un plan eterno de la predestinación en Cristo y un plan de la Encarnación en el tiempo, entre la razón y la fe. Peró la polémica donatista es como un catalizador que da carácter específico a esos cambios, al colocarlos en una situación histórica y existencialista. Tales cambios fueron denunciados como una recaída en el maniqueísmo ${ }^{1}$ y las $R e$ tractationes dan testimonio de ellos ${ }^{2}$.

Está ya sobreseída la polémica de la «conversión de Agustín al platonismo» ${ }^{3}$, pero se deja sentir en variadas formas, como aconteció en la polémica sobre la influencia del Ambrosiaster ${ }^{4}$ un tanto convencional ${ }^{5}$ y que en definitiva es la evolución y progreso del concepto de Cristo ${ }^{6}$. Se da pie a polémicas entre un cristianismo como Iglesia universal de los predestinados y un cristianismo como Iglesia revelada en los documentos bíblicos positivos ${ }^{7}$, o a polémicas entre ruptura entre un anterior concepto filosófico de religión universal y una posterior Iglesia existencial, fuera de la cual no hay salvación ${ }^{8}$. En fin,

1. Contra Julianum, I,1,1 y 3 PL 44,641 s.

2. Retractationes, I,9,1-6 PL 32,593-598.

3. COurcelle, P., Recherches sur les «Confessions» de S. Augustin, 1950.

4. BoUNAIUTTI, E., La genesi della dottrina agostiniana in torno al peccato originale, Roma 1916.

5. Casamassa, A., Il pensiero di S. Agostino nel 396-397, Roma 1919.

6. Brown, P., Augustine of Hippo, London 1967, p. 146-147.

7. Reuter, H., Augustinische Studien, Aalen 1967; Nygren, G., Das Prädestinationsproblem in der Theologie Augustins, Göttingen 1956.

8. Burns, P.; The Development of the Augustine's doctrine of operative grace, Paris 1980. 
ese conflicto puede generalizarse entre un anterior «interiorismo agustiniano» y un posterior «exteriorismo eclesiástico» ${ }^{9}$.

Algunos pensadores hallan un fuerte interés en el estudio de Agustín precisamente por ese carácter conflictivo, que parece inherente al pensamiento humano en su sinceridad. El antropomorfismo inicial y fundamental de Agustín sobre la «religión racional», el escepticismo o criticismo académico, tan semejante al de Lactancio, que reclama la necesidad de la fe como conditio sine qua non, el rechazo del fideímo ỳ oscurantismo de Tertuliano, el empeño de concordar la fe con la razón, separan a Agustín del hombre medieval y lo asocian al hombre moderno, gracias a la «interioridad». Se rechazan la credulidad viciosa y el racionalismo exclusivista, se reclaman los praeambula fidei $\mathrm{y}$ la exégesis concienzuda de la Biblia, y se busca una metafísica del hombre, una zona que hoy llamamos el inconsciente, en el que se juntan lo natural y lo sobrenatural. Nos alejamos, no sólo de Aristóteles, sino también de Descartes y Kant, para tender la mano a Freud y Hartmann ${ }^{10}$. Y sobre todo, después del Vaticano II, en que brotan ciertas aspiraciones ál ecumenismo y la unidad, el estudio de Agustín es una constante reflexión sobre nuestros problemas actuales, a la luz de la meditación de un gran genio.

El cristocentrismo es ya en Agustín inicial, pero va pasando por distintas fases evolutivas. Al principio Cristo es el Logos, el Maestro Interior, y como tal es el primum principium cognoscendi. Se establece como ideal el Deum et animam y también el quaerere Deum et vitam beatam; pero se trata de un ideal, de una tendencia propia de la unidad dinámica del hombre. En efecto, Dios es un Deus absconditus: no sabemos qué es Dios y sólo sabemos lo que no es Dios. Si no nos cerramos en una teología negativa es precisamente por la revelación de Cristo y porque la fuerza del ideal o unidad dinámica del alma humana no nos deja descansar hasta llegar a un Dios Absoluto. Aun al final de su vida continúa Agustín afirmando que de Dios sólo podemos hablar «por espejo y en enigma»: sólo conocemos imágenes pálidas de Dios ${ }^{11}$. Si alguien pretende hablar de un teocentrismo, deberá limitarse a ciertas vaguedades espirituales, heredadas de la filosofía.

Es verdad que, durante un corto período, Agustín mismo sintió el saram-

9. Malberg, F., Ein Leib-Ein Geist, Freiburg 1960; Bouyer, L., L'Eglise de Dieu, Paris 1970: «Equivoques de l'Ecclesiologie augustinienne». Acusa a Agustín de ultra-espiritualismo platónico, pero incurre él mismo en un constante equívoco; JouRNET, Ch., L'Eglise du Verbe Incarné, Friburg 1962: reivindica «la gran doctrina de S. Agustín». Cfr. CongAR, Y., Ecclesia ab Abel (Abhabd. über Theol. u. Kirche. Festschr. f. Karl Adam), Düsseldorf 1952; ID., «Civitas Dei et Ecclesia»: Rev. des Études August. 3 (1957) 1-14; ID., L'Eglise de S. Augustin à l'epoque moderne, Paris 1970.

10. SCIACCA, M.F., La interioridad objetiva, Barcelona 1963.

11. De Trinitate, XIV,9,15 PL 42,1068s. 
pión platónico, y proyectó una visión mística del Dios-Verdad. Al concepto platónico del ideal cognoscitivo se unía el testimonio bíblico, según el cual Adán veía a Dios cara a cara en el Paraíso; es decir, contemplaba directamente la verdad y a su luz lo veía todo sin equivocación posible. Si ahora el alma humana no ve a Dios, es por los impedimentos que ella misma se ha creado contra su propia naturaleza. Pero, aparte de que se trata de un período muy corto, se trata también de una veleidad, de fórmulas copiadas de los platónicos y de proyectos de futuro, que nunca tuvieron realidad. Quedó en pie, y eso era importante, una cierta visión apriorística de Dios, que significaba contacto con Dios, unión con Dios (subiunctio), y podía servir incluso para demostrar la inmortalidad del alma. Pero, mientras esa visión mística se desvanecía como mera ilusión, surgían los conflictos entre ese platonismo y las teorías «existencialistas» que Agustín iba recogiendo del cristianismo. La mística de Plotino es contradictoria, en cuanto que el hombre se une a Dios en una «tiniebla», y por el contrario es «unión transformante» de la consciencia. Lo que Agustín buscaba es una «visión», no un abrazo tenebroso. Para Agustín Dios es personal, libre, creador, no el Unum físico de Plotino ${ }^{12}$.

El platonismo no hablaba de la Encarnación del Logos, que viene a mezclarse con la carne, que entra en el tiempo y en la historia, en el régimen real de vida humana. En el cristianismo Cristo no es sólo «Camino» y «Verdad», no es sólo doctrina y ejemplo de conducta, sino también «Vida» de la humanidad. Agustín procura concordar el neoplatonismo con el cristianismo, y cree noblemente en esa posibilidad; pero el problema es arduo: el Verbo no sólo «ilumina» al hombre, sino que tiene que «liberarlo», «redimirlo», y para eso tiene que asumir una auténtica naturaleza humana, que crea un nuevo horizonite de problemas ${ }^{13}$.

\section{Desarrollo del concepto de pecado original}

«El Padre crea por el Hijo», significa que crea per Verbum y ad Verbum, según se trate de criaturas irracionales o racionales. De ese modo, el Verbo es principio ejecutivo y formal de la creación, Virtus et Sapientia Dei. El mismo concepto de Logos en cuanto Deuteros Theos podía ser aceptado por un cristiano como cristocentrismo cósmico y antropológico. Pero además, el Verbo

12. Ese período se termina en Tagaste: Videmus enim nunc in aenigmate (De Gen. c. Manich. II,5;6 (L 34,199). Cum jam ab eis sol occideret, id est, auferretur lux illa interior veritatis. (Id. II,16,24 PL 34,208). Post peccatum interclusum est ad tum ad sapientiam (Id., II,22,34 PL 34,214).

13. De Ordine, II,9,27 PL 32,956; De vera relig. 16,30 PL 34,135 . 
es la Luz Increada, de la que participa toda criatura racional: Él ilumina, como Maestro Interior a todo hombre que viene a este mundo, y por eso es para el hombre el primum principium cognoscendi, al que se subordina el concepto de Dios. Al verificarse el traspaso de una emanación a una creación, se imponía un «plan de creación», que sin duda llegaba hasta los últimos pormenores. Implicaba, pues, un «orden de predestinación» u «orden de salvación», anterior al problema de la libertad humana. Dentro de ese plan y de ese orden, la predestinación de Cristo y de los hombres en Cristo, la creación del hombre en el Paraíso, el pecado original, la redención, vocación, justificación y glorificación son meros episodios del drama creacional. Pero las últimas consecuencias no eran fáciles de detectar y Agustín tuvo que irlas explorando poco a poco ${ }^{14}$.

Por ejemplo, en el Libro II del De Genesi ad litteram, el concepto de pecado original sufre, no una ruptura, pero sí un cambio profundo. Agustín aceptaba la doctrina tradicional cristiana, pero quizá le daba un sentido excesivamente filosófico. Ahora era preciso darle un sentido histórico y existencial, tomando el Génesis como narración histórica. Pero esto significaba muchas cosas: eliminación del «eterno retorno», para aceptar la dispensatio temporalis, el tiempo lineal con principio y fin; se desvanece la ilusión paradisíaca de ver a Dios en este mundo, al aceptar la situación de miseria en que el hombre vive; desaparece la mística de la «visión directa» y sólo nos quedan las «mediaciones» Cristo, la Iglesia, la Biblia, la fe, la razón, etc.) para unir el cielo con la tierra, cultivando una mística de la Imagen, que termina en Cristo, «Imagen» del Dios invisible. Sin duda, Agustín sigue creyendo en una mística de la iluminación interior, puesto que en el pecado original no se perdió «la reliquia de la imagen»; pero esa mística es también mística de Cristo, cristocentrismo, ya que es la iluminación del Maestro Interior. Fuera de Cristo, el hablar de Dios es un tanteo de ciegos, que palpan las paredes para ver si tocan a Dios. Es el Verbo el que ilumina a todos, incluso en el A. Testamento ${ }^{15}$.

La conexión del maniquísmo con el pecado original cobraba una nueva luz en este período. El maniqueo Fortunato rechaza el concepto de «libertad humana», que Agustín presenta como «raíz del bien y del mal». Fortunato apunta a un hábito, que no procede de la repetición de actos, que es independiente de la libertad y que domina al hombre. Agustín confiesa que se trata en efecto de una delectatio carnalis, adherida a la misma naturaleza humana. Fortunato triunfa, pues obliga a Agustín a confesar que hay una «raíz de la raíz», que nunca había querido aceptar. Esa delectación carnal es, al parecer,

14. Bernard, R., La Prédestination du Christ Total, selon St. Augustin, Paris 1965.

15. MAYer, J.L., Les missions divines selon St. Augustin, Friburg 1960, p. 154-162. 
una inclinación al mal y esto reclama una explicación o justificación. ¿De dónde procede? Agustín tiene que recurrir al concepto de pecado original, y a sus dos consecuencias inmediatas, la concupiscencia (dificultas) y la ignorancia, que tienen sentido penal y no natural. Agustín se ve, pues, en un aprieto.

Al mismo tiempo explica a sus amigos de Cartago las Epístolas de S. Pablo a los Romanos y Gálatas. Su intención es desalojar definitivamente a los maniqueos, que se repliegan a S. Pablo, y a su teoría de las dos leyes (la de los miembros, o carne, y la del espíritu), como a un reducto inexpugnable. Pero queda casi alucinado al encontrar en S. Pablo todo un mundo nuevo. Al leer con la Vulgata in quo (Adam) omnes peccaverunt, desarrolla su pensamiento orgánico: todos estábamos en Adán en el Protoplato, como razones seminales: todos sufrimos las consecuencias del pecado natural u original. En cuyo caso el hombre queda sometido al pecado. Pero ese pecado no es «moral», sino natural: es una energía que nos domina, que nos inclina, que limita nuestra libertad hasta una raya indeterminada: es, pues, un principio trascendente, aunque no sea maniqueo. Y la contrapartida la ofrece el mismo pecado original, en cuanto origina un «regimen de redención y de liberación». Mientras los maniqueos hablan del Salvador, los cristianos hablan del Redentor. Satán y Cristo, el pecado y la gracia, el mundo y la Iglesia no serán principios maniqueos, ya que el mal es un parásito del bien y «no hay mal que por bien no venga». Pero queda en claro que sin Cristo, ya no se puede dar un paso en ninguna teoría religiosa existencial ${ }^{16}$.

Las consecuencias comienzan a revelarse en el Libro de las 83 Cuestiones. Se invoca el problema de la predestinación y de la vocación (Cuestión 65) y sobreviene el problema de la Ley. Dios permitió el pecado original, como permitió la crucifixión de Cristo, para obtener un mayor bien. Gracias a ese pecado, tenemos un orden de la Redención y un Redentor divino, como tenemos entre los hombres tantos héroes y «santos». Y gracias a ese Redentor podemos hablar en serio acerca de Dios, tal como se revela en la faz de Cristo. De este modo, el pecado original se convierte en punto de partida para la revisión del sistema agustiniano y su progresivo desarrollo.

Curiosamente se aducen contra Agustín en este período dos objeciones contradictorias: mientras unos le acusan de recaída en el maniqueísmo otros le acusan de ruptura con su ideología anterior para crear una suerte de cristianismo nuevo. No hay mucho que insistir en la objeción de maniqueísmo, puesto que el mismo Agustín la rechazó y refutó satisfactoriamente, mostrando la línea lógica de su catolicismo anterior, a pesar de las modificaciones coyuntura-

16. SCHNEIDER, R., Welt und Kirche bei Augustin, München 1949, p. 44ss. 
les. En cambio, la objeción de «ruptura» es actual y adopta diferentes formas. En principio diríamos que Agustín no ve en S. Pablo un negador de la filosofía o de la racionalidad, sino un apoyo. Así por ejemplo, Agustín descubre en S. Pablo la identificación de la ley natural con la ley divina. Mientras el Libro de la Sabiduría (Sab 13,9) reprochaba a los paganos el no haber conocido a Dios, S. Pablo afirma que lo conocieron (Rom 1,18s). Mán aún, Agustín estima que la mística de los Hechos (Act 17,28), propia de los estoicos, es identificada por S. Pablo con la mística cristiana de la interioridad («En Él vivimos, nos movemos y somos»). Esa mística natural, mística natural y sobrenatural de Cristo, es sin duda para Agustín la «verdadera religión».

En general, -los autores que hablan de teocentrismo y de «rupturas», alegan que las Enarrationes, en las que tanto se insiste en el cristocentrismo y en el Cuerpo Místico, son un recurso piadoso y no una teoría científica y racional. Pero no se detienen a demostrarlo: En cambio, nos hablan de un teocentrismo verbal ${ }^{17}$, o pretenden demostrar que el cristocentrismo de S. Agustín no es el de S. Pablo, como si sólo S. Pablo fuese cristocentrista, y como si la interpretación individual de S. Pablo fuese un dogma. Así sucede que tales autores nos hablan de Zeus, de un Dios genérico, de un Unum abstráto o físico, Primer Motor, Causa, etc., y no de la Santísima Trinidad cristiana. En segundo lugar recurren a superar la humanidad y la divinidad de Cristo, como si Cristo no fuese Dios, olvidando el per Christum hominem ad Christum Deum. Olvidan que también S. Pablo habla de Dios Padre y podría hablarse de su «teocentrismo» ${ }^{18}$. Olvidan finalmente que la fe cristiana era una mística y no una teología dialéctica: así confunden un Cuerpo Místico con un cuerpo dialéctico. No vemos que los partidarios de un «teocentrismo» se enfrenten a fondo con esas cuatro razones del cristocentrismo agustiniano. La «Teología Dialéctica» de K. Barth reunía las dos series de prejuicios, la dialéctica y el llamar místico a Plotino, Echkart y Schleiermacher. Pero es curioso que esa misma teología dialéctica confiese que toda supuesta mística cristiana tiene su fuente principal en S. Agustín, confesando que él es «el príncipe de los místicos» ${ }^{19}$.

17. Manrique, A., «Teocentrismo y cristocentrismo en S. Agustín»: La Ciudad de Dios 183(1970) 90-99.

18. Así se cae en el equívoco y la ambigüedad: «S. Agustín ha elaborado una teología primordialmente teocéntrica... La meta es Dios. Pero ésta sólo la logra alcanzar quien se identifica con Cristo» (ID., Id.).

19. LOMEYER, E., Urchristliche Mystik, Darmstadt 1956, p. 9. 


\section{El desarrollo del concepto de gracia}

Si la doctrina del pecado original desarrolla el cristocentrismo, eso mismo diremos del concepto de gracia. La gracia podía anteriormente reducirse a la gratia creationis o a la gracia santificante o a una de las mil formas con que Agustín la presenta al comenzar este período: el Evangelio, el Nuevo Testamento, la doctrina cristiana, el ejemplo de Cristo, los dones de Dios, etc. Ahora, el enfrentamiento con la delectatio carnalis reclamaba un desarrollo. En efecto, ¿el pecado natural es un principio enérgico que nos empuja al mal? Necesitamos, pues, otro principio enérgico y trascendental, cuya función consiste en superar la presión del pecado y liberarnos de ella, con ventaja. Por eso la lucha de Agustín en defensa de la libertad humana que se veía comprometida en este juego de dos principios trascendentales, tiene un gran dramatismo: « $i$ Venció la gracia!», es decir, es preciso rendirse a la evidencia. Los enemigos de Agustín podían considerarle hereje o innovador, si no penetraban en las profundidades del problema. Y por otra parte, esa postura de Agustín, a pesar de su evidencia, resultaba amenazadora: al convertir los «entes» en «criaturas», éstas quedan desamparadas, reducidas a meras potencias obedienciales que tienen que recibirlo todo de la gracia divina. Todo bien, grande, mediano o pequeño viene de Dios, y el mismo «ser» es ya un bien, un «existir».

Cuando Pelagio comenzó a predicar que la gracia divina era la misma naturaleza, se sentía orgulloso de la defensa que Agustín había hecho de la libertad humana y se negaba a entrar más adentro en el misterio de esa libertad, como más tarde se lo reprochó Agustín. Agustín podía haber replicado a la fórmula pelagiana «todo es naturaleza» diciendo «todo es gracia». Pero se dio cuenta de que ambas fórmulas podían coincidir en el fondo, reduciéndose a cuestión de palabras y por eso tuvo que acentuar la distinción entre la gratia creationis y la gratia redemptionis, entre la Gratia Dei y la Gratia Christi. No se trataba sólo de un problema filosófico, sino también teológico, y era preciso someterse a la razón y a la revelación. En este período, ya ve Agustín el problema entero con claridad. Porque ni la ley natural ni la ley escrita, podían, según S. Pablo, dar al hombre la salvación. Ya no bastaba la mera redención radical y universal, ni tampoco la fe individual o social, sino que era preciso descubrir la fuente de la energía moral para superar la tiranía del pecado en que vivimos sumergidos en nuestro orgullo. $\mathrm{Y}$ todo eso sólo podía realizarse en Cristo.

¿Como puede producirse la delectatio victrix sobre la delectatio carnalis? ¿Sin duda por obra de la gracia? Y esa gratia, ¿no comprometerá la libertad? Agustín cree que no sólo no la sustituye, sino que la ayuda; es un auxilio liberador, que se produce en una zona profunda del hombre, que podríamos llamar inconsciente o metafísica, en la que lo «natural» y lo «sobrenatural» se 
conjugan fuera del alcance de nuestras miradas y de la psicología aristotélica, cartesiana o kantiana. Ahí se juntan la trascendencia y la inmanencia. Y al cabo, es inútil nuestra investigación, ya que nos debatimos dentro de un misterio. La psicología termina en metafísica, y nosotros sólo tenemos competencia en aquello que podemos conocer o saber. Sin duda el hombre es «libre», pero su libertad está condicionada, ya por el pecado, ya por la gracia, aparte otros condicionamientos humanos. Lo que Agustín ve claro es que es preciso mantener el terreno «moral», junto al terreno metafísico y al terreno religioso, que no podemos controlar, ya que se trata de dos principios trascendentales, el pecado y la gracia.

Nunca defendió nadie la libertad humana con tanta energía y entusiasmo como Agustín. Pero fue comprobando la inutilidad de sus esfuerzos ${ }^{20}$. Se vio obligado a recurrir a la gracia de Cristo, que nadie puede tampoco controlar, pues procede de Cristo. Así entra Agustín en el cristocentrismo de S. Pablo, es decir, en lo que él creía leer en S. Pablo, aunque hoy se discuta de otro modo el sentido histórico crítico de los textos paulinos, con mayor o menor fortuna. Sabemos, eso sí, que las interpretaciones agustinianas iban siempre más allá de los sistemas que adoptaba; por ejemplo, el maniqueísmo, el escepticismo, el platonismo y no puede extrañarnos que también el cristocentrismo de $\mathrm{S}$. $\mathrm{Pa}$ blo sufra en manos de Agustín un desarrollo ulterior, según vemos en esta teoría de la gracia actual, que ha de superar la ignorancia y la concupiscencia. Vemos, pues, en este período de Agustín que el cristocentrismo no puede deternerse en S. Pablo ${ }^{21}$ y el Vaticano II ha mostrado que la gracia de Cristo es otorgada a todos los hombres que de un modo o de otro se han de salvar, pues todos ellos son el Cuerpo Místico.

No es, pues, posible hablar de teocentrismo al estilo del De Natura Deorum, de Cicerón ${ }^{22}$. En el Padrenuestro, Cristo nos proclama coherederos suyos, recibidos en la adopción de hijos, según piensa Agustín ${ }^{23}$. Y la libertad humana es requerida constantemente para colaborar con Dios, con Cristo ${ }^{24}$.

La predestinación del mismo Cristo es un argumento fundamental. En cuanto hombre fue predestinado sin mérito alguno a la unión hipostática y co-

20. Laboratum est quidem pro libero arbitrio voluntatis humanae, sed vicit Dei gratia (Retract. II,1,1 PL 32,629).

21. Boublick, V., La predestinazione. S. Paolo e S. Agostino, Roma 1961. El Espíritu Santo continúa «enseñando» y «sugiriendo» en la Historia de la Iglesia $(J n 14,20)$.

22. Los cristianos adoptaron con facilidad la tradición estoica, pues muchos de ellos venían de profesiones retóricas y pensaban que el cristianismo les ayudaba a superar las dificultades que los escépticos oponían a los estoicos. Cfr. De Serm. Domini in Monte, I,22,75 PL 34,1266.

23. Ibid., II,4,46 col. 1276. La llamada «prueba noológica agustiniana de la existencia de Dios» tiene un sentido profundo, que aquí no podemos exponer.

24. Ibid., I,22,75 col. 1266. 
mo «primogénito entre muchos hermanos». Nadie es hombre sino por Adán y nadie es predestinado sino por Cristo, y la consecuencia última que se dibuja es que todos los hombres son cristianos de algún modo, que toda la humanidad está conectada con Cristo en el plan de la creación y que el Cuerpo Místico es el organismo de todos los predestinados. La historia de la salvación viene a coincidir con la dispensatio temporalis ${ }^{25}$. Más aún, por la encarnación podemos decir que Cristo es no sólo principio soteriológico, sino también principio cósmico, que abarca al plano natural y al sobrenatural. El que todos sean cristianos de un modo y no lo sean de otro modo, es una de tantas paradojas de Agustín. Esas paradojas desembocaron con frecuencia en un misterio y eso no es extraño, ya que vivimos sumergidos en el misterio. Pero nunca se produce la contradicción o la división, sino la concordia, la unidad. No tenemos derecho a escandalizarnos, pues podríamos escandalizarnos igualmente de Cristo, y por eso a veces lo que llamamos «fe» no es sino «viciosa credulidad». Creemos lo que no sabemos por la autoridad de quien nos lo revela o inspira. Pero sería un delito afirmar que sabemos lo que no sabemos. Es claro que para Agustín la encarnación era ya el principio de la redención, principio de nuestra elevación, como el pecado de Adán fue principio de ruina ${ }^{26}$. Predestinación, pecado original y gracia de Cristo no son doctrinas separadas, sino piezas de un pensamiento orgánico unitario ${ }^{27}$.

Es curioso el proceso de Agustín. Al principio de su forcejeo era un perfecto pelagiano. Dando un paso hacia atrás, creyó que, por lo menos estaba en nuestra mano el no querer pecar, aunque pequemos ${ }^{28}$. Se hizo semipelagiano, atribuyendo al hombre el initium fidei. Pero la fe y la caridad se ven comprometidas por la gracia liberante y auxiliante, sin la cual serían inútiles o imposibles ${ }^{29}$. La figura de Cristo cobra entonces extraordinarias dimensiones ${ }^{30}$, mientras Agustín se aferra a la fórmula nostrum est credere et velle ${ }^{31}$. Finalmente Cristo rompe todos los impedimentos y otorga la verdadera libertad, cuando Agustín exclama: «jvenció la gracia!».

Pero eso no le impide mantener su idea de la «verdadera religión». Por el

25. BERNARD, 1.c., Des cieux nouveaux, une terre nouvelle: tels étaint même pour un Augustin, le fruit et le prix du sacrifice de la croix. Cfr. MoONEY, Ch. F., Theilhard de Chardin et le Mystère du Christ, Paris 1968, p. 123. Por eso es Cristo-principio cósmico y antropológico, natural y sobrenatural», «principio de coherencia», del sistema agustiniano, como dice el P. MADEC, G., «Le principe de cohérence de la doctrine augustinienne»: Rech. August., 10 (1975).

26. Bavel, T., Recherches sur la Christologie de S. Augustin, Friburg 1954, p. 74,85ss.

27. Expos. ad Rom. 13,18 PL 34,2066.

28. Ibid.

29. Ibid. 19 y 26 col. 2066; 2068 y 2072.

30. Ibid. 56 col. 2073 y 2075.

31. Ibid. 
contrario, se afianza en ella, religión única para todos los hombres. Admite los Libros Sibilinos, y hasta las profecías de los vates y de los poetas: in eis aliquid quod ad Christum pertinet invenitur ${ }^{32}$. Los semina veritatis, que se encuentran en todas las religiones y filosofías, son patrimonio de Cristo y de los cristianos, que han de apoderarse de ellos, como los israelitas se apoderaron de las riquezas de los egipcios, al huir. Cuando nos explica el caso del centurión Cornelio, nos hace ver que el soldado agradaba ya a Dios con sus oraciones y limosnas, aunque no pertenecía al pueblo escogido, y aunque no estaba bautizado. Por eso fue llamado por Dios mediante la palabra de S. Pedro ${ }^{33}$. Así fue llamado S. Pablo, y así son llamados todos en formas más ocultas y modestas. El Espíritu Santo, que sopla donde quiere, no puede ser encadenado por los israelitas o por los cristianos; la figura del cristocentrismo, en su presentación de Cristo total abre innumerables perspectivas.

Así vemos cómo en este período los cambios que introduce Agustín abarcan mil facetas: la fe, la caridad, la unidad, el concepto de mundo, de hombre, de iglesia, de catolicismo, de existencia, de orden natural y sobrenatural, de psicología profunda y de metafísica del hombre, de los sacramentos, ritos, palabras o signos, de la gracia adscrita a las fórmulas o palabras sagradas (Hieroi logoi), a las instituciones jerárquicas, a las tradiciones, etc. Hay en Cristo esferas reservadas a su divinidad, a su humanidad, a ambas en cuanto Cuerpo Místico, a la Iglesia invisible o visible, a ambos aspectos complementarios, a la Iglesia en cuanto «mundo liberado» o «mundo de los predestinados», etc., pero lo importante es reunir todo eso en un pensamiento orgánico y ese es el hombre genial de Agustín ${ }^{34}$.

Es, pues, necesario ir retocando las piezas del sistema. La kenosis de Cristo es humildad, respuesta al orgullo de Adán, que quería ser «como Dios». El yugo de la fe es por un lado humildad, sacrificio de la razón (rationabile obsequium), pero por otro lado es exaltación, edificio que sube desde cimientos profundos. La caridad cristiana va sustituyendo a la contemplación filosófica, que se relega a la vida futura, a la escatología. La mística de la visión de Dios deja su lugar al estudio afanoso, al rastreo de las imágenes, a las mediaciones, etc. ${ }^{35}$. El orden descendente desde Dios a los hombres pasando por Cristo ${ }^{36}$, implica ya el orden ascendente de los hombres a Dios pasando por Cristo y por su Iglesia ${ }^{37}$. Queda ya muy lejos el De Regresu animae, de Porfirio. El

32. Ad Rom. inchoata Expos. 3 PL 34,2089.

33. Ibid., 17 col. 2116 y 2123. Id.; 2101.

34. Ibid. ibid,

35. Ibid. 25 col. 1224.

36. De Serm. Domini in Monte, I,7,18 PL 34,1238s.

37. En el «Templo de Dios» (1Cor 3,17$)$ habita Cristo (Ef 3,17$)$ con nosotros por la fe en el 
Cristo total es una construcción grandiosa ${ }^{38}$ ut omnes in Christo unum sint ${ }^{39}$. Es, pues, cierto que el problema de la predestinación es la «quintaesencia de la teología», como afirma Nygren ${ }^{40}$, aunque él exagera buscando contradicciones. Él reprochaba a Courcelle el haberse limitado al análisis de los textos, cuando el estudio reclamaba una plataforma más amplia ${ }^{41}$. Y él incurre en el mismo defecto, al limitar el problema de la gracia a una pieza del problema de la predestinación ${ }^{42}$. En realidad el problema es total, y no admite otras limitaciones que las metodológicas, para proceder con orden ${ }^{43}$.

«hombre interior». De Serm. Domini in Monte, I,10,27 col. 1242; I,11,32 col. 1245. Cristo asumió nuestra naturaleza para darnos la doctrina y el ejemplo, juntamente con la vida (Ibid. I, 19,58 col. $1260 ; 1261 ; 1268$, etc.

38. Ibid., II,12,42 col. 1288. Al entrar en el estudio de S. Pablo, el carácter individual se complementa con el social. La fe y la caridad, van a convertirse en la argamasa y cemento de una iglesia.

39. Expos. ad Gal. 28 PL 34,2125s. Es el Christus Universus, hoc est Caput cum corpore suo, quod est Ecclesia (Quaesti. 83, q.69 PL 40,79. Cita concretamente Gal 1,16,28 y 2Cor 12,27. No sabemos si por este tiempo conocía ya la obra de Tyconio sobre el Cuerpo de Cristo. En cambio, afirma que son muchos los textos bíblicos que hablan de ese Cristo universal (Ibid). Ahora es perfectamente clara la conexión de los problemas: somos coherederos, hijos adoptivos, aceptados en el «testamento» que Cristo firmó con su sangre redentora, como se sancionaban los sacrificios en el V.T. (De Div. Quaest. 83, q 75,1-3 PL 40). El Cristo, que habita en nosotros, se va formando dentro de nosotros (Expos. pos. ad Gal. 38 col. 2132), pero dentro de un pensamiento orgánico, puesto que el Cuerpo de Cristo es una Iglesia (De Serm. D. in Monte, I,5,13 PL 34,1236. Se explica por qué Agustín comienza a prestar atención al ejemplo de las dos esposas de Abraham, citado por S. Pablo: todos son hijos de Abraham, pero unos de la esclava y otros de la libre (Expos. ad Gal. 40 PL 34,2133.

40. NYGREN, l.c., p. 8s.

41. Courcelle, P., Recherches sur les Confessions de S. Augustin, Paris 1959.

42. El contexto fundamental es el de la «verdadera religión», pero hablando concretamente es el mismo concepto de Dios. Agustín en su maniqueísmo, aceptaba una iglesia de predestinados, en la que entran todos los que se salvan. En consecuencia ¿después de su conversión, el contexto es el mismo concepto de un «Dios verdadero», esto es, de un Dios Creador? ¿acaso puede admitirse un Creador que crea sin un plan, sin un proyecto, sin saber lo que hace? El mismo Nygren reconoce que el problema de la predestinación va ligado al de la presciencia y al de la providencia. Y S. Agustín se admiraba de que la predestinación causase escándalo en gente que admitía presciencia y providencia de Dios. No entramos aquí en la discusión analítica del problema de la predestinación. Nos remitimos al citado estudio de R. Bernard, La Prédestination du Christ total. En consecuencia, lejos de ver en ese problema una paradoja irreconciliable con la libertad humana o con la universal voluntad salvífica de Dios vemos la solución o cúspide de los problemas que preocupaban a Agustín. Naturalmente, eso no significa que Agustín esclareciese totalmente lo que es y sigue siendo un misterio: lo fue para él y lo es y lo será para nosotros.. Tampoco significa que Agustín haya terminado su evolución intelectual en este período, como veremos en el párrafo siguiente. Significa que en todo esto no hubo ruptura alguna de la evolución intelectual, sino un desarrollo notable, producido en gran parte por influencias internas, pero según el rumbo del pensamiento orgánico de Agustín.

43. Congar, Y., L'Eglise de S. Augustin à l'epoque moderne, Paris 1970, p. 12. Aprovecha las primeras Enarrationes, que Agustín redactó siendo presbítero, antes de su episcopado y afirma que Agustín conocía bien las reglas de Tyconio desde el 395. 


\section{La polémica donatista}

El cambio que el pensamiento agustiniano revela en este período, fue siempre motivo de discusiones, a veces contradictorias. Aparte las objeciones ya mencionadas, antes del Vaticano II se consideraba a Agustín «peligroso» por su doctrina de la Ecclesia ab $\mathrm{Abel}^{44}$. Después del Concilio y pasando al extremo contrario, se le considera peligroso por su fórmula extra Ecclesiam nulla salus ${ }^{45}$. Esto ya no es extraño, pues en realidad siempre se consideró a Agustín como «peligroso», cuando alguien no se atreve a enfrentarse con la Iglesia o con S. Pablo. Pero en este caso, parece indudable que Agustín mismo da pie al recelo, ya que es evidente el cambio que se produce en este período: de una «interioridad» se pasa a una «exterioridad» o visibilidad. ¿Y qué significa eso? De un eterno presente helénico se pasa a una historia, a un tiempo lineal; de un individualismo se pasa a un socialismo; de la unidad (Henología) se pasa a las «unidades» temporales; del Cristo-Logos, se pasa al Cristohombre; de una Iglesia sin mancha ni arruga se pasa a una institución eclesiástica; de una teoría del sacramento como revelación se pasa al sacramento como signo visible; de las palabras sagradas ieroi logoi) se pasa a las fórmulas que parecen mágicas; del hombre atento al Maestro Interior se pasa al hombre obediente al clero; de la oración jaculatoria se pasa a la recitación de oraciones comunes; del campo de los deseos se pasa al campo de las oraciones vocales; de una exégesis bíblica libre se pasa a una reglamentación metódica de la exégesis; de un crede ut intelligas se pasa a un crede et in coelo intelliges; de un cristianismo platonizante y esencialista se pasa no a un cristianismo positivo, sino positivista y existencialista, etc. Aunque no puede hablarse de «ruptura», el cambio es tan notorio que en realidad todas las piezas del sistema son retocadas a conciencia para mantener y desarrollar el pensamiento orgánico.

No queremos decir que Agustín renunciara a la «interioridad», ya que por el contrario vemos que insiste más en ella y se aferra a ella con mayor energía y profundidad. Lo que queremos decir es que el mismo concepto de «interior» sufre un cambio notable, al ser aplicada a la nueva situación. Para poder mantener la «unidad» de las diferentes unidades que ahora van surgiendo, tiene que irse acomodando a la nueva situación. Así, por ejemplo, la fe no es ya una sencilla interioridad. No es sólo un camino hacia la inteligencia, una

44. Malmberg, F., Ein Leib, Ein Geist. Von Mysterium der Kirche, Freiburg 1960. Era una cadena de téologos agrupados en torno a TromP, S., Corpus Christi, quod est Ecclesia. I. Introductio generalis, Roma 1937. Eran mirados con recelo Congar y De Lubac: ConGAR, Y., «Ecclesia ab Abel» (Fests. f. Karl Adam) Düsseldorf 1952)); DE LuBAC, H., Meditation sur l'Eglise, Paris 1953.

45. No es posible exigir a S. Agustín la amplitud de miras del Vaticano II, o de los. estudios posteriores. S. Agustín era de su tiempo y de su mundo, y no tenía en cuenta el hinduismo, el bu- 
conditio sine qua non de la misma inteligencia, sino que es ya inteligencia; no es ya sólo la via regia et popularis, que se opone al método aristocrático de los helenos, sino que sustituye poco a poco a la misma inteligencia, convirtiéndose en la Cristo, filosofía del cristiano, y filosofía del hombre en este mundo. No es formulación de un lenguaje simbólico sino un intelligere credendum credendo. El hombre está instalado en la historia, en la miseria, no en el paraíso filosófico.

Lo mismo acontece con el concepto de Iglesia. Ya no es sólo «la iglesia de los predestinados», que se revela en la escatología, sino que en la tierra la Iglesia es jerárquica e institucional, aunque abierta a una interioridad más profunda. Así como la fe tiene que mantener su alianza con la inteligencia, así también la visibilidad de la Iglesia ha de mantener su alianza con la invisibilidad de la misma, formando unidad y no conflicto: aumentan las tensiones, pero nunca se llega a las rupturas, sino a unidades más potentes. Creación, predestinación, existencia e historia se reclaman recíprocamente en el mundo, ya que el tiempo recibe su sentido y valor de la eternidad. Si preguntamos Cur Deus homo? tenemos un Cristo mediador, maestro, redentor, camino, verdad, vida, etc. Pero, ya que Cristo entró en la historia, nació, murió y está sentado a la diestra del Padre, hay que preguntar Cur Ecclesia? Y entonces tenemos la misma respuesta: porque Cristo necesita mediaciones y sigue siendo pastor, médico, maestro, redentor, etc. Y no sólo eso sino que la Iglesia misma necesita mediaciones y entonces hay que seguir preguntando Cur sacramenta? Y la respuesta seguirá siendo la misma. .

En efecto, los problemas del cambio van a revelarse con claridad en el concepto de «sacramento», ya en cuanto rito sacramental, ya en cuanto gracia sacramental. Es necesario ir concretando, puesto que ya no es suficiente el concepto de sacramento como «signo», alegando el omnia in figuris contingebant illis $(1$ Cor 10,11$)$. Porque precisamente sobre ese concepto se centra la polémica donatista, a propósito del bautismo y de la rebautización. El bautismo es un signo, pero muy especial, como que «caracteriza» al pueblo cristiano y fue establecido para este régimen de la tierra. Es, pues, necesario ante todo, pasar a una «exterioridad social» instituida y convencional, que se ha conver-

dismo, el islam, etc. Su mundo era el de los herejes, cismáticos, judíos y paganos de tipo grecorromano. Pensaba, pues, que el triunfo total del cristianismo era inminente, tal como se presentaba la historia. Le resultaba más fácil que a nosotros creer en una incorporación real del mundo a Cristo. Pero ya es maravillosa la amplitud de miras que manifestó, muy lejos de la visión tribal o nacionalista de su tiempo. En este sentido podemos aceptar su espíritu, pues nos ofrece unas bases teológicas muy de acuerdo con las discusiones teológicas y técnicas de la actualidad. Lo que hace falta es plantear bien las distinciones: no es lo mismo hablar de là redención universal de Cristo, $o$ de la. unidad de los que viven «en Cristo». 
tido en materia de un pleito, no sólo eclesiástico, sino también humano. Pero sería absurdo prescindir de una «interioridad» más profunda que Agustín llamará la res sacramenti, tan profunda que pasa a ser trascendental. También aquí suben las tensiones, aumenta la energía, pero nunca se llega a la «ruptura).

Diremos lo mismo del concepto de gracia. Ya no es la gracia de los israelitas tan sólo, ni tampoco la gracia de los griegos tan sólo. Ahora se confía a la gracia la misión de superar la tiranía del «pecado». Los defectos del pecado son notorios, sociales, universales. Los efectos de la gracia son también evidentes, en especial las llamadas «conversiones» a las que Agustín confiere un gran valor. No es, pues, suficiente decir que la gracia divina es el Evangelio, la doctrina o el ejemplo de Cristo, el Nuevo Testamento, etc. Es preciso explicar hechos clamorosos, como la conversión del mismo Agustín. Pero lejos de renunciar a la «interioridad» tenemos que sumergirnos en ella, hasta llegar a la «raíz de la raíz». La raíz moral del hombre era la libertad, y ahora esa libertad aparece condicionada por esas energías que llamamos pecado y gracia. Como en los casos anteriores suben las tensiones, aumenta la energía, pero nunca se llega a la ruptura ${ }^{46}$.

Ahora bien, el cambio, lejos de ser ruptura, es un desarrollo del pensamiento orgánico ${ }^{47}$. Porque la superación de estos posibles conflictos que pueden provocar las tensiones, se producen en una interioridad tan interior que obligaba a Agustín a no renunciar al platonismo, para aprovechar esa zona que hoy llamamos inconsciente o subconsciente. En esa zona laten la consuetudo carnalis, el pecado original con su ignorancia y concupiscencia, la libertad humana, la gracia divina, y hasta diríamos que laten en esa zona, no sólo la sociedad, sino también la Iglesia y Cristo. Pero en esa zona no penetra el ojo de la inteligencia, sino.indirectamente: es un misterio en el que ni la ciencia, ni la filosofía tienen competencia. Pon lo tanto, es inútil discutir «opiniones y prejuicios» en nombre de la expreriencia, de la ciencia, de la filosofía, de la teología o de la religión. Lo único que podemos saber con seguridad es que lo visible y lo invisible constituyen unidad, y por lo mismo el Corpus Adam y

46. Hay, pues, motivo para preguntarse si hay ruptura o continuidad (cfr. BuRNS, J.P., The developement of Augustine's doctrina of operative gráce, Paris 1980: «Agustín nunca volvió a su anterior perspectiva individualista» (Id., p. 53-86). «El presente capítulo va a demostrar el cambio de perspectiva» (Ibid.). Otros hablan de continuidad: «Por la Encarnación se acepta la autoridad divina, pero sin renunciar a la razón filosófica (Cfr. MAILLARD, W., «The Incarnation in Augustine's conversion»: Rech. August. 15(1980) 80-98, p. 98). La encarnación es el principio de coherencia del pensamiento agustiniano (MADEC, G., «Le principe de cohérence de la doctrine augustinienne»: Reche. August. 10(1975).

47. KönIG, H., Das organische Denken Augustins. Paderborn 1966, p. 103. 
el Corpus Christi, el organismo natural y el sobrenatural constituyen el UNUS HOMO ${ }^{48}$.

Otra consecuencia es que la unidad del pensamiento orgánico contempla la realidad como una «situación», que sobrepasa la libertad individual. Un hereje o cismático puede tener caridad o unidad o paz «objetivas», pero son «falsas», ya que se oponen a la situación real de la Iglesia: «tienes el bautismo, pero no tienes la caridad, pues has dividido la unidad» de la única paloma (Una est columba mea. Cant 6,8). Por ende, una cosa es que tú creas amar a tus hermanos, y otra que tu caridad sea auténtica si non fueris in unitate. La única paloma lleva consigo la caridad, unidad, paz objetivas y verdaderas. En cambio, son falsas la caridad, unidad y paz del cuervo, aunque intente imitar a la paloma. Esa unicidad de la Iglesia lleva también consigo la unicidad del bautismo, pues bautiza Cristo, no Pedro ni Judas, aunque Cristo se valga de sus ministros para bautizar. Por lo cual todos los hombres, potencialmente, constituyen la Iglesia, pues se dijo: ite docete omnes gentes, baptizantes eas (Mt 28, 19) que corresponde al salmo 2,8: dabo tibi gentes haereditatem tuam. Cristo con su humildad y con su caridad repara la discordia y división de lenguas de la torre de Babel, reuniendo a la humanidad en un pentecostés cristológico. Fuera de esa unidad, pueden darse muchos bienes, que pertenecen a la católica, pero no sirven de provecho, mientras la persona no esté realmente implantada en la unidad, es decir, mientras ponga óbice o impedimento a la circulación de la vida de Cristo, que es su gracia.

Agustín había planteado con cierto optimismo el problema de la «verdadera religión», identificándola con el cristianismo católico. Pero ahora le salía al paso el problema de dos «confesiones», que en el fondo eran dos tipos de religión, uno de ellos universalista y otro nacionalista. Y Agustín en su Salmo abecedario, destinado a la propaganda, reclama con insistencia la paz, la unidad, la concordia, una concordia que por sus motivaciones religiosas era imposible.

El donatismo era un fenómeno complejo. Presentaba aspectos sociológicos, económicos, racistas, militaristas, revanchistas, martiriales, de lenguaje, de revolución, de independencia, etc. Era natural que provocase una reacción espontánea de paz y concordia ${ }^{49}$. Agustín ensayó las alegaciones y estudios sobre el hecho y sobre el derecho del cisma. Pero al m omento comprobó que

48. Agustín utiliza los símiles bíblicos (Esposo-esposa, cepa-sarmientos, etc.). Pero prefiere el de cabeza-cuerpo porque.expresa mejor el concepto de «organismo» que es sobrenatural, pero muy realista: In Jo 6,4-14 PL 45,1427-1432.

49. Ep. 33,5 PL 33,97 . 
todos esos procedimientos interminables eran inútiles, ya que.en el fondo latía siempre el problema religioso fundamental ${ }^{50}$.

La suerte vino en su ayuda, al arrojarle a la cara desde el principio el problema de la rebautización, obligándole a hacer una «teólogía desde abajo» y a establecer un fundamento antropológico para estudiar el concepto básico de «sacramento» que daría sentido a los demás problemas. Era, pues, necesario discutir el bautismo en su doble aspecto, visible e invisible, como sacramento de la Iglesia, de Cristo y de Dios, como realidad histórica y como concepción teológica: es un sacramento que es también una regeneración. Aquí el plan de la predestinación ha de conjugarse con la dispensatio temporalis: es un hecho con valor de eternidad. Era también necesario distinguir el sacramentum de la res sacramenti, la visibilidad, el signo, y también la gracia sobrenatural, invisible y divina. Esto era tan importante que lógicamente llegaría a imponer una visión sacramental del mundo ${ }^{51}$.

Como siempre; Agustín va mucho más allá de lo que la polémica reclamaba, pues sú pensamiento orgánico le obligaba a mantener un sistema riguroso. Lo que va a plantear es, en suma, el derecho de Cristo al género humano y el derecho del género humano a participar en Cristo. Oponerse a ello, eso es el cisma ${ }^{52}$. Y puesto que ahora se trata de un «pleito», no puede haber otra ley, ni otro criterio de discusión que la Biblia ${ }^{53}$. Sin embargo, la Biblia no habla del cisma; y por ende, es necesario interpretar y aplicar los textos, y aquí

50. Algunos autores estiman que Agustín no comprendió bien el carácter «sociológico» del donatismo. Son ellos los que no comprenden el fondo religioso y total de aquel fenómeno. Los marxistas se empeñan en presentar el donatismo como ejemplo de «lucha de clases», cuando en realidad era una lucha de los terratenientes romanos contra la administración central; en esa lucha los proletarios y siervos no tenían nada que ganar ni que perder. Agustín discutió directamente frente a los donatistas vivos, mientras que nosotros «proyectamos» nuestra experiencia moderna en formas indebidas. El fanatismo donatista contradice a todas nuestras argucias. Cfr. Ep. $43 \mathrm{PL}$ 33,159-173).

51. Agustín había utilizado el término sacramentum con libertad, como símbolo o signo, especialmente bíblico o ecleșiástico. Pero el donatismo obligaba a tener en cuenta el valor del sacramento, su utilidad o inutilidad, o ruina. La fórmula paulina judicium sibi manducat et vivit $(1$ Cor 11,29$)$ había de ser aplicada y puntualizada en el caso concreto del bautismo, en el que a veces (como ocurre en el bautismo de los niños) el individuo tiene «representantes».

52. Por eso desde el Principio Agustín planteó su esquema: gentes sunt haereditas Christi, et possesio Christi termini terrae. La cita del salmo se convierte en una profecía y en un testamento de Dios a su Hijo, y la realidad de la Iglesia universal responde al cumplimiento de esa profecía. Ante esa argumentación, todo lo demás es accidental: tollamus de medio inanis objeta. Ep. 23,6 PL 33,97.

53. Harnack pensó que Agustín incurría en un círculo vicioso, al apoyar la Iglesia en la Biblia y la Biblia en la Iglesia. Es una falta de reflexión y de lectura. Porque Agustín nunca apoyó el valor de la Iglesia en la Biblia, sino viceversa. Podemos salivarnos sin la Biblia, pero no podemos sin la Iglesia, y no se aceptaría la Biblia misma si no la presentase la Iglesia. No se trata, pues, de ese problema ahora. Del que se trata aquí es de un pleito jurídico, que impone sus propias condiciones de pleito entre dos partes, o «confesiones», dentro de la Iglesia y con Biblia en la mano. 
comienzan las dificultades ${ }^{54}$. La dificultad es tan grande, que si bien Agustín se atiene a un esquema sencillo y riguroso, se ve al fin obligado a recurrir a la Tradición, es decir, a una situación eclesiástica anterior al cisma, y aceptada por ambas partes contendientes ${ }^{55}$.

También tuvo suerte Agustín al encontrarse con Ticonio, el cual, aunque donatista por falta de lógica, defendía que la Iglesia tenía que ser universal, y que su valor no podía quebrar por errores, abusos o pecados humanos; además, se había preocupado por el concepto de «cuerpo de Cristo», que le venía muy bien a Agustín, aun con las debidas enmiendas. De ahí que ya en la réplica a Parmeniano se desenvolvió con libertad triunfal ${ }^{56}$. Parmeniano trataba de refutar a Ticonio con textos bíblicos, incurriendo en una continua y ridícula torpeza: no se atenía a la revelación, sino a la opinión de los obispos donatistas, mientras que Ticonio comparaba la profecía del Antiguo Testamento con la realidad del Nuevo, y se atenía a una revelación que parecía clara ${ }^{57}$. Es la del donatista una «temeridad sacrílega», pues la unidad de la humanidad se. funda en Cristo: totum orbem terrarum in Christi humanitate fundatum. Se trata, pues, de un pleito universal, del derecho de Cristo y del género humano,

54. Los donatistas citabar la Biblia sin cesar y Agustín va refutando sus interpretaciones con toda seriedad, aunque muchas veces las citas son ridículas. Por eso se veían enredados cuando Agustín insistía siempre en unos pocos, pero vigorosos textos.

55. El concepto de Sacramentum, como veremos tenía antecedentes concretos y por eso los problemas podían surgir en muy diversas direcciones. $Y$ por eso decimos que fue una suerte para Agustín encontrarse con el problema de la rebautización, para no salirse del tema central. (Ep. 23,2 PL 33,94; sacramentum sedentis in coelo (Id., n. 4) «non exuflo vexillum regis mei (Id., id.). Es una disputa sobre Cristo: de ipso Capite nostro tan turpis inter nos et pernitiosa dissenssio est (Id., n. 5 col. 131); Christi Corpus diversa communione dilaniant (Id. id.; Ep. 34 y 35 PL 33,133 y $134) ; E p .43,8,21$ PL 33,170). Las discusiones sobre la historia del cisma sólo valen para hómbres de buena voluntad, no para fánáticos de mala fe. Agustín tenía la ventaja de haber meditado el concepto de «verdadera religión» (De Vera Relig. 6,10 PL 34,127). Su libro y testigo en el pleito es el género humano.(Ep. 43,9,25 PL 33,172).

56. Contra Ep. Parmeniani, I, 1,1 PL 43,34s). Ticonio escribió un libro, que intituló De las Reglas, pues recogía siete normas para interpretar pasajes oscuros de la Biblia (De Doctr. christ. III,30,42 PL 34,81). Agustín no oculta la utilidad que Ticonio le prestó con su libro, no sólo en cuanto le permitió continuar el De Doctr. christ. que tenía interrumpido, sino también por el servicio a la cristología y a la eclesiología, al redondear el concepto del Cuerpo Místico. En efecto, la primera regla de Ticonio se titulaba De Domino et ejus corpore explicando que a veces un texto se refiere a la cabeza, a veces a ambos como una eademque persona (Ibid. III,31,44 PL 34,82). Precisamente entonces Agustín trataba de explicar cómo algunos textos bíblicos se referían a la divinidad de Cristo, otros a su divinidad y así se decía que era igual al Padre y otras que era inferior (De Div. Quest. 83, q. 69.9 PL 40,78). Al exponer la segunda regla de Ticonio De Domini corpore bipartito, descubre Agustín su íntimo pensamiento; Piensa que Ticonio puso mal el título y que debió decir De Domini corpore vero atque permixto, o bien, vero atque simulato, ya que no pertenece en realidad ál cuerpo de Cristo quien al fin estará separado de Él (De Doctr. christ. IIt,37,44 PL 34,82). Como ocurre siempre, Agustín al leer a Tíconio, va mucho más lejos que él, pero es claro que el libro de Ticonio le prestó un inmenso servicio, al dejarle completa libertad para interpretar las locuciones metafóricas, simbólicas y figuradas.

57. Contra Ep. Parmen. I,2,3 PL 43,36). 
de la verdadera religión, y no de un pleito eclesiástico, o de una serie de contiendas de todo linaje, como quieren los donatistas, al entender el «pecado» como una mancilla biológica ${ }^{58}$.

Con frecuencia los donatistas aducen textos de un modo tan ingenuo, que en realidad se vuelven contra ellos, y eso acontece justamente cuando se trata del bautismo. Porque, si la unidad del género humano se funda en Cristo, si la unidad de los cristianos se funda también en Cristo, ya que Él es el principio formal y ejecutivo de la creación y origen de los predestinados, el bautismo aparece como principium conjunctum, que explica el modo de nuestra unión con Él ${ }^{59}$. No hay, pues, muchos bautismos, sino uno solo, pues siempre es Cristo el que bautiza, mientras se bautice en nombre de Cristo. Ese bautismo de Cristo puede ser inútil y aun perjudicial, según la fórmula paulina de la eucaristía (Judicium sibi manducat), que Agustín aplica a todos los sacramentos y carismas. Hay indigne accipere, que puede convertirse de impedimento en veneno, como ocurrió, según S. Agustín, en el caso de Judas (Jn 13,26). Y no basta escudarse en una supuesta buena voluntad «subjetiva», ya que una «situación general» como la que plantea un cisma claro, condiciona visiblemente la libertad individual y no es fácil o es imposible deslindar lo subjetivo de la objetivo. Es, pues, necesario estar en la unidad, y después hablar de la unidad subjetiva.

Como se ve, Cristo va invadiendo los dos planos, el de la creación y el de la predestinación, unificando a cada uno de ellos y unificándoles entre sí en el orden natural y sobrenatural. Es ya para los hombres la unidad, el UNUM, que corresponde a Dios, ya que para los hombres es el primum principium cognoscendi en todos los órdenes.

¿Quién es, pues, Cristo? Siguiendo a S. Pablo, Agustín reconoce a Cristo como Logos, como principio formal y ejecutivo de la creación, que fue hecha per Verbum et ad Verbum. Le reconoce así como principio antropológico, de iluminación y de predestinación. Así, la incorporación a Cristo en el tiempo es una cristificación: Nec tu Me mutabis in te... sed tu mutaberis in $\mathrm{Me}^{60}$. Para esa plena cristificación no es ya suficiente la iluminación divina, que se da a todo hombre, ni la mediación divina, o asunción de la naturaleza humana,

58. Id., $1,7,12$ col. 42 .

59. Dominus noster emit totum mundum pretio sanguinis sui (D. Ep. Parmen. I,7,12 PL 43,42). Cur non sinis ut semper sit Christus origo christiani, in Christo radicem christianus infigar, Christum christiani sit Caput (C. Litte. Petiliani, I,5,6 PL 43,248s). Cum quis Christi baptismo baptizatur, Christum baptizare fateatur, de quo solo scriptum est. Hic est qui baptizat (Jo. I,33) (C. Ep. Parmen. II,12,24 PL 43,67; II,13,30 col. 72s; II, 10,21 col. 64s). Como la argumentación es siempre la misma, en el libro Contra Petiliano bastará decir: Petilianus dixit... Augustinus respondit. (In Jo, 6,6 y 8 PL 35,1428 y 1432).

60. Confess. VII,10,16 PL 32,742). 
que es general para todos los hombres; ni basta la gratia creationis, como tampoco las gracias particulares o carismáticas, que Dios puede otorgar a quien quiera; es necesaria una incorporación real y social, que garantice la fórmula paulina in Christo. Y para realizarla se necesita ese principium conjunctum, como en el caso de la generación humana. No hay pues regeneración en el sentido eclesiástico, sin bautismo. Era, pues, natural el recurso al texto joáneo: nisi quis renatus fuerit ex aqua et Spiritu Sancto... (Jn 3,5). Por consiguiente, el sacramento del bautismo implicaba la trasmisión de la vida sobrenatural, la regeneración, o segundo nacimiento (renatus).

Pero es preciso entrar en el plan de la predestinación, pues nadie se salva sin ese principio vital que es Cristo. Petiliano trataba de ridiculizar la respuesta de Agustín a Cresconio, como si Cristo bautizase visiblemente. Agustín replica con vigor: non visibili ministerio dicimus... sed occulta gratia, occulta potentia in Spiritu Sancto... Nec iam baptizare cessavit, sed adhuc id agit... Ipse invisibiliter mundat, et hoc universam prorsus Ecclesiam... Nemo sibi arroget quod Dei est ${ }^{61}$.

La distinción que en el De Doctrina Christiana se marca entre signum y res tiene aplicación inmediata. Ya no se puede interpretar el término spiritus a capricho, sino que el sentido bíblico impone la identificación de spiritus con res. El rito y la gracia no pueden separarse, pero tampoco confundirse. No había dificultad mayor para entender el sacramentum, pues se utilizaba un material tradicional y una polémica sobre la «rebautización». La tradición del $s a$ cramentum provenía del militarismo romano, de las religiones mistéricas y del cristianismo. Las tres tradiciones tenían mucha fuerza en Agustín. Del lado clásico vivía la tradición de los legionarios, con sus banderas (Vexillum) y sus juramentos al emperador (Sacramentum), con sus tatuajes y su organización jerárquica, tal como podemos comprobarlo en Séneca. De lado de las religiones mistéricas, Agustín había leído la Metamorfosis de Apuleyo yạ en los ban$\cos$ de la escuela y conocía el lenguaje de la militia spiritualis ${ }^{62}$. De lado cristiano, Tertuliano y Lactancio, habían aprovechado el «Mysterium» cristiano y el juramento militar para presentar un bautismo lleno de poderío y vigor. $Y$ como siempre, Agustín iba todavía más allá, pensando en su concepto de la gracia actual.

61. Contra Litt. Petil. III,49,59 PL 43,378s). De ahí viene la conclusión extra Ecclesiam nulla salus, que equivale a decir que el pleito donatista tiene una sola conclusión: «los donatistas no están en la Iglesia católica». Eso es ya suficiente y causa finita est. (De Unitate Ecclesiae 4,7 PL 43,396). Si de algún modo podemos hablar de la «dialéctica» de Agustín, ha de ser dentro de su pensamiento orgánico y de su obsesión por la UNIDAD.

62. Cfr. Emondas, H., Geistlicher Kriegdienst. Der Topos der «militia spiritualis» in der antiken Philosophie: Heilige «Uberlieferung (Festschi. f. Herwegen 1938). Da nomen sanctae huic militiae, cuius non olim sacramento etiam rogabaris) Apuleyo, Metamosphoseon, XI,15). 
Los donatistas habían recibido de S. Cipriano, autoridad para ambos bandos, el tema de la rebautización: los «indignos» o «pecadores», que se identifican con los herejes, no poseen el Espíritu Santo y no pueden darlo a los demás; de ese modo los «traditores» quedaban excluidos de la Iglesia, pues son «pecadores». Pero el «pecado» es para Agustín otra cosa, moral, personal, interior, y no sólo acontecimiento social. Esos donatistas se enorgullecían, puesto que Agustín aceptaba la validez de su bautismo. ¿Cómo podía ser «pernicioso» un bautismo «válido»? Creían, pues, que se trataba de las acostumbradas «retóricas» de Agustín, y por eso «no querían discutir, sino rebautizar». Y es curioso, como han observado algunos teólogos, que Agustín parece otorgar con excesiva generosidad el valor del sacramento, al estilo de los antiguos ${ }^{63}$. En realidad, parece que se refiere al bautismo entero, y no sólo al rito, o fórmula del mismo, entendiendo que el conjunto tiene ya por sí mismo un sentido católico, como se comprueba en el bautismo de los niños o de algunos que in articulo mortis no tienen ya clara consciencia del bautismo que han solicitado.

Pero el problema era para Agustín mucho más grave, pues el cisma era ruptura de la relación de Cristo con el género humano. Si las profecías bíblicas eran claras y su cumplimiento era evidente ¿qué podía haber acontecido para romper esa relación? ${ }^{64}$. El bautismo es, pues, problema central de la «verdadera religión», según la Biblia; todos los hombres tienen derecho a él, de manera que Cristo y el mundo están ligados: maior liber noster est orbis terrarum. Aunque Cristo es el que bautiza, la Iglesia es visible, es una ciudad edificada sobre el monte, que nadie puede ignorar: hanc ignorare nulli licet ${ }^{65}$.

Es curioso el modo como se busca una «ruptura» en el pensamiento de Agustín en este período: «En el De Vera Religione, Agustín veía a Dios ocupándose de la humanidad como un todo, haciendo accesible el camino de la salvación. Esta perspectiva no sobrevive en los comentarios paulinos: en ellos Agustín recae en lo individual, en lugar de seguir; por ejemplo, la meditación

63. ¿Acaso basta pronunciar la fórmula trinitaria cristiana para dar validez al rito bautismal? Quizá el que bautiza no tiene intención de bautizar, o el bautizado no la tiene de recibir el bautismo, sino que se trata de una parodia o de un sacrilegio. Quizá un hereje pronuncia bien la fórmula, pero dándole un sentido diferente del católico, si no tiene idea de una Trinidad católica. Parece, pues, que Agustín sobreentiende que se trata de una ceremonia seria y que el hereje conserva el sentido católico, como era el caso concreto de los donatistas. Era sin embargo necesario rechazar la fórmula «No queremos discutir, sino rebautizar», que quería dar por resuelto el problema. Cfr. Ep. 33 PL 33,129; Ep. 34,35,43, etc.

64. ¿Por qué razón o causas podría Cristo haber perdido su derecho y su herencia universales, que son la Iglesia? ¿Acaso por un suceso tan extraño como el de los supuestos «traditores»? ¿No se contradecían los donatistas al otorgar validez al bautismo de los «Maximianistas», para no provocar un nuevo cisma? (Cfr. Ep. 49,3 PL 33,190; Ep. 51,5 PL 33,193.

65. Ep. 52,1 PL 33,194. Agustín no podía pensar en las religiones del Oriente o de América. Además, creía inminente el triunfo tal del catolicismo. 
de Pablo sobre la misión y destino de Isarel» ${ }^{66}$. Este modo de hablar es confuso: parece decir que Agustín abandona la universalidad filosófica, y entra por un camino individualista, propio de la interioridad personal. Pero se ocultan aquí varias falsedades. No es verdad que Agustín abandonase la via regia et popularis, que había opuesto a Porfirio y había fundado en la fe cristiana, como condición sine qua non para entender. Lo que observamos en este período es todo lo contrario: un aumento del sentido social, de la visibilidad, de los sacramentos, jerarquías, mediaciones, exterioridades. Además, se buscan diferencias entre S. Pablo y Agustín para asignar a éste el conflicto entre la libertad y la gracia, eximiendo a la Biblia y a S. Pablo de tales conflictos.

¿El pleito donatista obligaba a mantenerse en la brecha? ¿Cuál es la «verdadera iglesia» o la «verdadera religión»? Para responder, era necesario destacar las «notas», los rasgos característicos de la misma, según la revelación y según la razón. Además, este segundo problema, no podrá resolverse sin el tercer problema que es la relación «Iglesia-mundo», ya que aquí entra el «destino y misión de.la Iglesia», del Novus Israel o Verus Israel, problema heredado de S. Pablo. El pleito no es, pues, sólo eclesiástico, y Agustín tiene que pensar en todos aquellos políticos paganos que le rodeaban, que eran sus amigos, y dudaban de ingresar en la Católica definitivamente. Era necesario urgir una auténtica «obligación» ${ }^{67}$.

«Sobre el que vieres descender el Espíritu Santo, es el que bautiza en el Espíritu Santo» (Jn 1,33). Si ese texto se convierte en un principio válido para todos, sólo cabe preguntar si ese bautismo es administrado «rectamente», como vimos arriba, esto es, en las condiciones católicas de seriedad y de buena intención. Porque Agustín va a abrir una nueva perspectiva, tomada también de S. Pablo: en esta regeneración, por semejanza con la generación carnal, los que engendran son el Esposo y la Esposa legítimos, Cristo y la Iglesia. Agustín ve que la generación implica un principio vital, independiente de sus portado-

66. No nos toca a nosotros explicar cómo un israelita, confesando que «todo le viene de Dios», puede resolver un problema que ni siquiera se plantea. Tampoco nos toca explicar cómo $S$. Pablo, aparte de meditar en la misión de Israel, como buen israelita, puede concertar la libertad humana con la gracia divina actual, pues tampoco se plantea ese problema formal. Pero en cambio, es claro que Israel y S. Pablo mantienen un concepto «tribal» de la salvación. A pesar del universalismo paulino, heredero de su «helenización» subsiste siempre una iglesia judía, que trata de universalizarse, extendiéndose y conquistando el mundo entero. Este modo de pensar ya no era posible en tiempo de S. Agustín, dominado del todo por la idea de la UNIDAD, y de la universali-

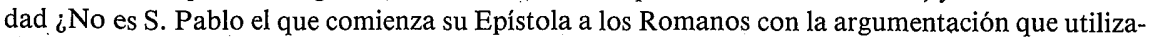
rá constantemente Agustín? ¿Y no nos presenta S. Pablo su propio caso como «individual»? En fin, sería largo desenredar los modos confusos de hablar. Pero por fortuna, el mismo Burns, a quien nos referimos, concluye de un modo inesperado: «La doctrina de la eficiacia de la gracia demuestra ambas cosas, también nosotros admitimos el «cambio», esto es, el desarrollo del pensamiento orgánico, pero no la ruptura, pues no creemos en ruptura alguna.

67. Cfr. Ep. a Firmo. Ep. 2, en Diviak, p. 9. 
res o ministros. Así acude de nuevo a S. Pablo para interpretar la generación de los hijos de Jacob, los de las esclavas y los de las libres (Lía y Raquel); éstas cedían a su marido las esclavas para la generación, pero eran ellas las que daban validez a esa generación legítima. Quien otorga validez al bautismo es la católica, no el donatismo. Por ese principio, tenemos cuatro clases de fieles: 1) católicos, representados en Isaac y Jacob; 2) bautizados por los cismáticos, pero reintegrados a la católica, representados por los hijos de las esclavas; 3 ) cismáticos puros, representados por Ismael; 4) católicos «pecadores», representados por Esaú. Logra Agustín dos ventajas: por un lado, el concepto del «pecador católico» le abre un nuevo campo de investigación: por otro lado, la validez queda separada de la utilidad: Est, sed nos prodest: el bautismo anormal es un collar con valor intrínseco, pero en el cuello de una adúltera, ya que la propiedad es de la esposa legítima ${ }^{68}$.

El caso del «pecador católico» para los donatistas carecía de importancia: su Pecado era social, identificado con la herejía y por eso llamaban «santos» a sus adeptos, aunque estuviesen cargados de pecados «morales» y personales. Para Agustín era un problema grave. El perdón de los pecados no se da sin el Espíritu Santo, y para ello se requiere una disposición interior. Si el donatista recibe un bautismo "válido», debería recibir el Espíritu Santo. Recurre, pues, Agustín al ejemplo de Simón Mago y de Judas. Aquél recibió el bautismo, pero no se le perdonaron los pecados por un «óbice» sacrílego ${ }^{69}$.

¿En qué consiste la «rectitud» del bautismo, en cuanto principium coniunctum, principio vital, o principio de la regeneración? ${ }^{70}$. El donatista puede decir: ya tanto una confesión como la otra reconocen que en el donatismo se de el bautismo de Cristo, me bautizaré en el donatismo. Agustín objeta: «no lo haces rectamente, según la confesión católica, porque antepones lo in-

68. - Itaque est una Ecclesia... et ipsa generat. De baptismo, I,10,14 PL 43,117.

69. No bastan la caridad y la unidad «objetivas», por sí mismas, para perdonar los pecados, sino que se requiere la disposición interior. Se supone, pues, que en el bautismo de los niños, de los moribundos, y de los que administran fuera de la Iglesia, hay recta intención «eclesiástica». En ese sentido se entiende que Cristo mandó bautizar «para el perdón de los pecados» (Mt 28,19; Jn 20,22), pero «haciendo penitencia» o metanoia. Simón Mago, obró maliciosamente, pero con seriedad; recibió un bautismo válido, pero infructuoso, por el óbice de su malicia. Si más tarde elimina o retira el óbice, no necesita rebautizarse, sino que en virtud de su bautismo válido se le perdonan los pecados. En cuanto a Judas, Agustín creía que Judas comulgó realmente antes de salir a entregar a Cristo: fue, pues, comunión «sacrílega», perniciosa, según la fórmula paulina: judicum sibi manducat. Por consiguiente, esos «dones de Dios» que son buenos y santos, pueden ser perjudiciales, como un veneno (Cfr. In Jo. 6,17s PL 35,1433s).

70. Desde el principio, Agustín relacionaba la rectitud con la intención dirigida a Dios o a Cristo: por eso había «virtudes viciosas». Ahora esa intención es equiparada a la caridad, tomando como base 1 Cor 8,1 ss. Ni la fe ni el bautismo son útiles sin la caridad, y ésta es incompatible con el cisma (De Baptismo, I,8 11 PL 43,116; In Jo. 6,21 PL 35,1435. 
cierto a lo cierto ${ }^{71}$. En cuanto a la Biblia, el caso del centurión Cornelio prueba la necesidad de incorporarse a la católica ${ }^{72}$. Los donatistas tienen muchas cosas buenas, pero tienen la úlcera de la «separación del Cristo» y eso basta. Bonum ex integra causa, malum ex quocumque defectu: Un enfermo puede morir de su úlcera, aunque tenga todos los demás miembros sanos ${ }^{73}$, y por ende, tiene que curar la úlcera del cisma, para que tengan eficacia la fe, la caridad personal, el bautismo. Eso es lo que exige la unidad de situación para una perfecta salud, la caridad «objetiva» o social, a la que se refiere S. Pablo (1Cor 13,1-3). Caifás profetizó (Jn 11,51), los demonios creyeron y confesaron (Mc 1,24), Simón Mago recibió el bautismo (Act 8,13).

El donatista aprovecha la confesión de Agustín: «ya que el bautismo de Cristo engendra hijos en el partido de Donato, y la Iglesia no puede ser más que una, el donatismo es la auténtica iglesia y no hay otra». Pero Agustín objeta: «engendra hijos, en cuanto está unida, no en cuanto está separada». Todas las religiones tienen algo de la católica, y por esa unión es ella la que engendra en todas las religiones, cismas y herejías, como ya vimos en la aplicación del caso de los hijos de Jacob. Y engendra precisamente por el principio vital del bautismo de Cristo, que se conserva en todas partes, si es auténtico. Del mismo modo, no están separados de la Católica sólo los socialmente separados, sino también muchos católicos pecadores, o que perseveran en la unidad de Cristo. Simón Mago estaba bautizado en la Católica, pero «no tenía participación en la heredad de Cristo» (Act 8,13,21). No fallaban el bautismo, el Evangelio, los sacramentos sed frustra natus est ${ }^{74}$.

La misma argucia utilizan los donatistas para arrogarse el perdón de los pecados. Pero Agustín vuelve al ejemplo de Simón Mago: Recibió un bautismo válido y por lo mismo ya no necesita «rebautización»; pero no se le perdonaron los pecados por su malicia, sacrilegio u óbice; entonces basta que retire el óbice para que el bautismo entre en su función salvadora, que estaba impedida y detenida ${ }^{75}$. Y eso se aplica a todos los tiempos. En el A.T. había justos,

71. Et sancta possunt obesse. In Jo. 6,15 PL 35,1432.

72. De Bat. I,8,16 col. 115 .

73. Id. I,8,11 col. 115; ostende mihi quomodo habeat charitatem qui dividit unitatem. In Jo. 6,14 col. 1432 .

74. Id. I,10,14 col. 117. Lo mismo puede decirse de los que promovían cismas en Corinto (1Cor 1-13). Ergo ipsa (católica) generat, et per uterum suum, et per uterum ancillarum, et eisdem sacramentis, tanquam ex viri sui semine (id. id.). Sed qui superbiunt et legitimae matri non adjunguntur, similes sunt Ismaeli, de qúo dictum est, ejice ancillam... (Id. id.). Por eso también el «pecador católico» es reprobado, como Esaú (Esau autem odio habui) porque aunque nació de la Católica y en ella, desdeñó la gracia recibida (Id. id.).

75. Tunc valere incipiat ad salutem. Id, I,12,18). Agustín confirma su doctrina con el ejemplo del siervo evangélico (Mt 18,23-35). Ese ejemplo prueba que, al faltar la caridad fraterna, los pecados «reviven». El Señor perdona al siervo la deuda; pero el siervo mantiene el odio y el rigor 
esto es, «espirituales» que pertenecían al N.T., occulte pertinentes; del mismo modo en el N.T. hay pecadores, «animales», que pertenecen al A.T., aunque, si tiene voluntad de conversión, per sacramenta, custoditi in terra viventium computantur ${ }^{76}$. Distintas son las iglesia que parieron por un lado a Abel, Enoch. Noé, Abrahán, Moisés, profetas, apóstoles, mártires, y por otro a Caín, Datán, Judas y herejes ${ }^{77}$.

Llama la atención el caso que menciona Agustín: los que son «animales», pero tienen intención de convertirse, son computados entre los que heredan la terra viventium. Parece, pues, que la misma comunión con la Iglesia, esto es, la caridad y unidad objetivas, perdonen los pecados del que muere sin haberse convertido aún, por sola la intención de hacerlo. El caso se presta a meditación, ya que podría decirse eso mismo del donatista, que tiene intención de incorporarse a la Católica. Esto tiene importancia para el ecumenismo actual. A primera vista, cambiamos los términos, pues Agustín dice que primero hay que buscar la concordia y después orar juntos, mientras muchos (pensamos en los que defienden la oración común para preparar la reconciliación) invierten los términos. Pero en el fondo hay coincidencia, ya que, si los hermanos separados se juntan a orar, es ya manifiesta su conversión, su unión espiritual, la «caridad de la unidad» ${ }^{78}$. San Pablo saludaba a todos los cristianos como santos, socialmente hablando, porque «la caridad cubre la muchedumbre de los pecados» (1Pe 4,8); los cristianos, aunque sean pecadores, moralmente ha-

con su consiervo; entonces el Señor hace valer de nuevo la deuda que había perdonado, pero que no tiene efecto definitivo por el óbice del odio y falta de caridad (Id. I,12,20 col. 120). Agustín añade: haec saepe contingunt in Ecclesia. Y explica que cuando se administra el bautismo in articulo mortis no da tiempo suficiente para un interrogatorio adecuado sobre el perdón de los enemigos. El enfermo es bautizado, y conserva el odio; pero si más tarde retira el odio es perdonado, no rebautizado. Se transmite, pues, el principio de vida sobrenatural que es Cristo, pero es preciso no separarse de ese Cristo por el cisma, para no quedar estéril y seco. Por eso fue Esaú «separado del pueblo de Dios», aunque había nacido de Rebeca (Id. I,15,23 col. 121); en cambio Aser, nacido de là èsclava fue incorporadó al pueblo elegido. Ismael fue también separado, pero no por nacer de la esclava, sino por la discordia fraterna (Id. id.).

76. De Baptismo, I,15,24 PL 43,123.

77. Es el tema de la Ecclesia ab Abel. Agustín compara su teoría con la del nacimiento biológico, en el que aparece primero una mano, luego el cuerpo y finalmente la cabeza (De Bapt. I,16,25 col. 123). Eso significa que puede pasarse del A. al N.T. y viceversa, ya que se mantiene la unidad del género humano, y la unidad de los predestinados y de los no predestinados. Lo que importa es que en «la última bielda», quede el hombre del lado del trigo y no de la paja. Porque si ha de quedar del lado de la paja ¿de qué le sirve su vida en la tierra? Y Agustín concluye: de nullo desperandum est, ya esté dentro ya esté fuera de la Iglesia jerárquica. De nada sirve, pues, excomulgar a un inocente, ya que ganará más con esa prueba de su caridad y unidad (Id. I,17,26 col. 123s).

78. Cfr. Babau, G., Traités Antidonatistes, vol. II, Desclée, 1964, p. 45. La comunión de los santos actuaría en nombre de Dios y la gratia Christi se uniría a la caridad objetiva. En ese caso el «pecador» estaba ya «en Cristo por el bautismo», pero la unión no producía sus efectos por el impedimento levantado. 
blando, colaboran con el Espíritu en la edificación del Cuerpo de Cristo. Se lamentan algunos teólogos de que Agustín se detuvo poco en los aspectos visibles de los sacramentos, de la Iglesia y de Cristo; pero ese mismo fenómeno prueba su cristocentrismo, ya que del concepto de Cristo dependen todos los problemas. En su tiempo se insistía quizá demasiado en el Logos, y se estudiaba ligeramente la humanidad de Cristo; era, pues, normal que se insistiera mucho en la Res sacramenti y en la Iglesia de los predestinados. Pero el fenómeno es universal, y no era posible otra cosa, dada la penuria de los estudios bíblicos y la imposibilidad de una exégesis crítico-histórica, verdaderamente científica. Y quizá nosotros pecamos del exceso contrario al encerrarnos en un positivismo bíblico, que a veces convierte la religión en arqueología. En Agustín se observa un notable progreso en este punto, como veremos en el libro $D e$ Trinitate.

San Cipriano había distinguido entre los pecadores que están in domo y los que están extra domum, aun reconociendo que en una gran casa hay también vasos in contumeliam ( 2 Tim 2,20). Pero esa distinción no vale para Agustín, pues el pecado moral es incompatible con el Espíritu Santo, dentro o fuera de la Iglesia. Y así su fórmula es peremptoria: non omnes qui tenent baptismum, tenent Ecclesiam; simul non omnes qui tenent Ecclesiam tenent vitam aeternam ${ }^{79}$. Hay, pues, tres clases: bautizados, eclesiásticos y predestinados.

Hay asimismo dos tipos de «caridad y unidad», la subjetiva y la objetiva, y en ambos representa Agustín un avance en la Tradición, forzado por las circunstancias de sus contiendas y por su pensamiento orgánico en torno a la verdadera religión de la humanidad.

Para S. Cipriano, el pecador católico pertenece a la paloma. Agustín en cambio, ve que ese pecador se ha separado de la paloma con sus actos personales y morales, incompatibles con el Espíritu Santo: avari, raptores, subsoli, ebriosi, flagitiosi: membra sint columbae hujus? Absit. Agustín hace ver la incongruencia de la postura donatista. En la Iglesia católica hay buenos y malos, grano y paja. Los donatistas creen que todos su adeptos son «santos». Y podrían llamarse así quizá en el sentido de S. Pablo o de S. Cipriano. Pero en el sentido donatista es una insolencia, ya que salta a la vista la cantidad de borrachos, ladrones, que todos conocen. Y Agustín arguye: si esos «pecadores» notorios y escandalosos se han separado de la Iglesia y del Espíritu Santo, ¿por qué no se los rebautiza, cuando se reconcilian con la iglesia donatista?

79. Los donatistas citaban Eccli. 34,25: qui baptizatur a mortuo... non ei prodest lavatio. Pero si es Cristo quien bautiza, ya no es un muerto (Contra Creasconium II,25,30 PL 43,484. C. Litt. Petiliani, I,9,10 PL 43,2507. 
Porque es evidente que no tenían caridad, y por lo mismo es evidente que se habían separado de la unidad ${ }^{80}$.

Diríamos que tales pecadores tienen una «fe muerta» y a veces se utiliza a Agustín para hablar de esa fe muerta. En realidad no se puede plantear formalmente en Agustín la fórmula del Concilio de Trento, al replicar a los reformadores, ya que Agustín no se planteó formalmente ese problema ${ }^{81}$. Puede hacerse la aplicación con cautela, distinguiendo los casos. Lo que no puede hacerse es hablar de «individualismo» en el sentido moderno, ya que eso es absurdo en el Imperio Romano. Seguimos cometiendo el mismo error de los medievales que hablaban de intelectualismo y voluntarismo, o de la distinción real entre el alma y sus potencias, etc., como si Agustín hubiese sido un aristotélico medieval. Podemos sin embargo, hacer aplicaciones con cautela, ya que Agustín pasaba de un esencialismo a un existencialismo cristiano ${ }^{82}$.

La unidad se impone siempre. Si Cristo es el Esposo y la Iglesia es su Esposa, tenemos que diferenciar los planos. La humanidad entera es Esposa de Cristo, pues Él asumió la naturaleza humana en el seno de María: en ese sentido la Iglesia es la humanidad entera. Pero en el plano de la predestinación, la Iglesia no es de hecho la humanidad entera, sino el número de los predestinados. La Iglesia es, sin embargo, única: una es mi paloma. Al preguntar ubi est Ecclesia, preguntamos en realidad ubi est Corpus Christi, para poder distinguir modos de pertenencia a Cristo. Así la respuesta es la misma sentencia de Cristo ${ }^{83}$. Pero subsisten el conflicto y el misterio: Agustín había reprochado a los maniqueos el que siempre quedaba una parte de la humanidad, no recogi-

80. In Jo. 6,12 PL 35,1431 .

81. Con. Trident. Sess. VI, cap. 21. Pueden hacerse comparaciones ya que tanto la unión o separación del pecador católico como la del donatista admite grados. Eso acontece también en el ecumenismo, manteniendo la fórmula agustiniana: sicut ergo est in Catholica quod non est catholicum, sic potest extra Catholicam aliquid esse catholicum. El catolicismo de Agustín, en cuanto reformador, es siempre un tanto idealizado, de acuerdo con la revelación bíblica y de la razón filosófica de la "verdadera religión».

82. Ese existencialismo implicaba la revelación bíblica concreta, la Iglesia concreta y temporal, la historia, el Cristo histórico y sus funciones concretas en este mundo, en cuanto CaminoVerdad-Vida, etc. Con frecuencia el teólogo puede abusar de los textos agustinianos, si no ha renunciado previamente al aristotelismo, a sus definiciones, distinciones y pies forzados. Es difícil para un teólogo actual colocarse bien en el ambiente y pensamiento del Imperio Romano. Sin embargo, los principios son universales y pueden aplicarse con cautela y muy diversas situaciones.

83. En este sentido podríamos dar a Nygren una parte de razón, ya que en efecto aparece un conflicto entre el "numero cerrado» de los predestinados y la humanidad que mantiene la «verdadera religión». Pero la cautela se impone ya que la teoría de la predestinación le venía a Agustín del maniqueísmo y no de sus estudios cristianos, a los que luego se acomodó. Por eso creemos que la predestinación angustiaba a Agustín aun en su vejez, ya que implicaba un cierto dualismo insoluble, un infierno eterno, como un campo excluido del amor de Dios, y mantenido sólo para demostrar el poder y justicia de Dios, como un alarde frente a algún enemigo. Más adelante veremos ese conflicto. 
da en el Cuerpo de Cristo. Y sin duda esa era también su angustia en el catolicismo, sobre todo después de Pelagio ${ }^{84}$.

Podemos reconstruir así el proceso progresivo y orgánico del cristocentrismo agustiniano. Durante su juventud maniquea, trató de concordar la religión con la filosofía, en busca de una religión racional. Vivió entonces un cristocentrismo soteriológico: Cristo viene a la tierra a recuperar a sus predestinados y reintegrarlos a la Patria, al Principio del Bien, que constituye ya, por decirlo así, un Cuerpo Místico. Ese Cristo-Salvador toma una figura humana para dirigirse a los hombres y así desempeña sus funciones fundamentales de «Camino, Verdad y Puerta». Al leer a los platónicos, se produce un cambio fundamental; no una ruptura, sino un desarrollo, una nueva y maravillosa perspectiva. El Cristo es ahora el Nous, engendrado por el uno, por emanación, y por lo mismo Medianero para el mundo animado por el espíritu o alma. Es ya «principio cósmico y antropológico. «Esa lectura de los platónicos se hace en un ambiente cristiano, y ya resulta imposible deslindar la influencia cristiana en el platonismo de Agustín, que en realidad no es platonismo. Lo que queda claro es la obsesión por la UNIDAD que Agustín lee en Plotino y Porfirio. De todos modos, a continuación se produce la lectura de S. Pablo y la conversión al cristianismo, y entonces Agustín acepta la encarnación del Verbo, de la que no hablaban los platónicos. Aunque Agustín, empeñado en concordar el cristianismo con el platonismo, para mantener su idea de la «religión racional», no tiene todavía un concepto cabal de Cristo, poco a poco va perfeccionando el sistema cristocéntrico, al ir asimilando los elementos cristianos. El Logos o Nous es el verbo bíblico, y como a tal se le aplica la idea paulina que lo constituye en Virtus et Sapientia Dei, esto es, en principio ejecutivo y formal de la creación (queda eliminada la emanación y con ella la necesidad dialéctica, introduciéndose la libertad en Dios y en el hombre). Al ser principio formal, todas las criaturas racionales son creadas ad Verbum y no sólo per Verbum. La razón o inteligencia es una participación en el verbo que es la fuente de la luz intelectual. Él es el Maestro Interior, que ilumina a todo hombre que viene a este mundo, constituyéndole en criatura racional e imponiéndole una religión racional, universal, única para toda la humanidad. Esta religión ha de identificarse con el cristianismo, tomado en un sentido genérico y un tanto ideal. Porque el Verbo se hizo carne y esto significa que asumió a la humanidad pecadora, significa otro cambio fundamental, una nueva perspectiva de desarrollo, aunque tampoco es una ruptura. En efecto, el problema Cur Deus homo reclama una respuesta adecuada. De momento bastará decir

84. Aquí se ve la inteligencia aguda y la mala fe de Juliano de Eclana en combatir a Agustín en aquellos puntos que él suponía eran su talón de Aquiles. Por eso Agustín no oculta a veces su nerviosismo, al responder a Juliano. 
que de un esencialismo hemos pasado a un existencialismo, de una concepción filosófica a una concepción histórica, de una eternidad siempre presente a un tiempo lineal, de una teoría hipotética a un régimen temporal, que se llama dispensatio temporalis. Naturalmente, esta dispensatio temporalis reclama a su vez una concepción adecuada, y Agustín encuentra las respuestas a su inquisición en el pecado original, en la gratia Christi, y en la Iglesia, según hemos ido viendo en este artículo. El hombre vive en el tiempo, pero no es un mero tiempo, ya que vive adherido (subiunctus) a la eternidad. La figura de Cristo es el supremo modelo de toda meditación humana, por ser DiosHombre, por ser tiempo y eternidad. Y como Él tomó parte en nuestra naturaleza humana, para hacernos partícipes de su naturaleza divina, es ahora plenamente Camino-Verdad-Vida de los hombres. En cuanto cabeza del cuerpo, que es la Iglesia, constituye, por decirlo así, dos aspectos de esa Iglesia. La Iglesia la constituyen todos los hombres sin excepción alguna, pues Cristo es el principio antropológico. Pero la dispensatio temporalis obliga a distinguir entre la situación potencial y la real, ya que no todos los hombres pertenecen efectivamente a la Iglesia, ya porque no ingresan en ella, ya porque no perseveran hasta el fin. Todos pueden ser «santos» y están llamados a serlo; pero unos no llegan a serlo y otros lo son en apariencia, pues quedarán separados en la última bielda, y no estarán con Cristo eternamente, según la concepción de aquellos tiempos. Hay, pues, aspectos visibles e invisibles, naturales y sobrenaturales, pero la Iglesia es una y única, inseparable Esposa de Cristo, en cualquiera de esos aspectos y según cada uno de ellos. El Cristo total será, pues, como dice el P. Madee, el «principio de coherencia» de todo el sistema orgánico.

Cristo es, pues, la respuesta a todos los problemas de Agustín. Desde Él se explica la fe, là Ecclesia ab Abel, el Verus Israel, la verdad o filosofía, la humildad, la «ascensión» humana en Cristo, tan diferente de las ascensiones platónicas, la kenosis, la ignorancia y concupiscencia humanas, la gracia actual, la caridad, la unidad. Cristo es también la vida divina que circula por ese organismo sobrenatural que llamamos el Cristo total.

Este es ya el cristocentrismo triunfante, que ha invadido el organismo natural de Adán y su linaje, manteniendo la distinción que impone la predestinación divina. El pecado y la gracia son principios trascendentales, que parecen amenażar a la libertad humana y nos preocupan a todos hasta hoy, aunque evitemos el hablar de ello por las exageraciones de Wicleff, Huss y Calvino. Un Dios sin predestinación es un Zeus, no un Dios, pues carece de presciencia, previsión, libertad, providencia y se convierte en una ficción filosófica. El pelàgianismo se enorgulleció al poner el dedo en esa llaga que es un misterio para todos. Agustín escribió sus Retractationes, confesando sus tendencias filosófi- 
cas y platónicas primitivas. Mientras rechaza con pasión a los maniqueos, nos hace ver que esos pelagianos recaen en el filosofismo y deberían ir lógicamente a parar a un emanantismo y panteísmo, a una necesidad y no a una libertad; a un Zeus y no a un Dios. Rechaza, pues, la acusación de recaída en el maniqueísmo, o de novedad eclesiástica, pero descubre bien que tanto el maniqueísmo como el pelagianismo son sistemas más profundos de lo que suponen sus opositores, pues analizan «la raíz de la raíz». La libertad humana no es absoluta ni es una simple ausencia de coacción externa: lo que importa es la carencia de coacción interna; lo que importa es definir la coacción interna; lo que importa es ver que la libertad no puede entenderse dentro de una simple ideología, sino más allá de toda ideología, en la metafísica del hombre, que el mismo hombre no puede conocer, sino adivinar. En una filosofía no cabe hablar de libertad, sino por una perpetua contradicción inconfesada, por pura ignorancia. ¿Qué hemos de entender por libertad y por coacción? ¿Son coacción o libertad el pecado y la gracia? ¿No vamos a detenernos en la delectatio victrix, fórmula genérica; mil veces explicada? Recordemos sin embargo que el pecado (ignorancia y concupiscencia) significan para Agustín un cierto tipo de esclavitud. ¿Cómo puede ser libre el hombre, nacido en la ignorancia y en la concupiscencia, crecido en el pecado? Es libre, pero con una libertad limitada y condicionada. Por eso la superación del pécado por la gracia es para Agustín una liberación, una extensión y facilidad en el campo de la libertad humana, aunque la gracia se reciba de Dios. Dios no suprime libertad, sino que la confiere, facilitando su ejercicio con motivos adecuados, como mociones adecuadas, valiéndose de la misma metafísica humana del inconsciente. Y por eso Agustín detesta tanto a los maniqueos y a los pelagianos: son ellos los que le han obligado a pasar las fronteras de la ciencia y de la filosofía para adentrarse en la metafísica, pero ellos no se han quedado rezagados en las redes de la psicología, de la sociología y de la filosofía.

$\mathrm{Y}$ así vemos cómo ha evolucionado el cristocentrismo agustiniano, desde una ideología filosófica hasta una metafísica abisal, hasta el misterio. Y entre las otras influencias el donatismo fue quizá el catalizador y al mismo teimpo la prueba de valor, la piedra de toque, en busca del organismo cristianouniversal. La cristología tenía, pues, que ampliarse y profundizarse para comprender el misterio de la Iglesia: era necesario pasar del. Logos-Verbo (déuteros Theós) al hombre libre, a la historia. Había que establecer de nuevo un principium conjuctum, semejante al de la creación, según el cual el Verbo participase en la naturaleza humana y el hombre participase en la naturaleza divima del Verbo. Como repite Agustín. El Verbo tenía que hacerse hombre, para que el hombre pudiese hacerse Dios. Y de este modo Cristo se convirtió en el Mediador universal y al mismo tiempo se cumplía la palabra de S. Pablo (Ef $1,22)$ «para que Dios sea todo en el universo» (1Cor. 15,28). 
Tal meditación de Agustín partía ya de la predestinación, pues Cristo es el primero de los predestinados y en él fueron predestinados todos y todo el universo. Al ser Primogénito entre muchos hermanos, la humanidad queda incorporada al plan de la predestinación. Y si hubiese mil mundos habitados por seres racionales, habría que aplicar la misma meditación en todas partes. Si fuimos predestinados en Cristo desde la eternidad, fuimos llamados libremente por la gracia, por la caridad, cuya fuente y vehículo es también para nosotros Cristo. Como se ve; todo esto, dicho someramente, no es «devoción» de un predicador, o propaganda espiritual, sino la construcción arquitectónica cristiana del organismo universal. Lo único que cabe plantear es saber si esto es mera teología o es ya propiamente una mística, lo mismo que acontece en S. Pablo. Nosotros pensamos que esto es una mística, y eso lo veremos al final.

Cabría un ajuste entre teocentrismo y cristocentrismo, si en lugar de hablar de Dios en sentido genérico (Zeus), hablamos de la Santísima Trinidad o en todo caso, del Padre, dentro de la revelación de Jesucristo. Ese mismo problema puede plantearse y resolverse en S. Pablo con el mismo sentido y valor que en S. Agustín, con la sola diferencia de las circunstancias. Y del mismo modo podríamos hablar de un ajuste entre teología y mística, si por teología entendemos, no un estoicismo bautizado, o un platonismo bautizado, sino el cristianismo concreto, como verdadera religión, como Cuerpo Místico de Cristo. Así quedaba para Agustín concretado el plan de su verdadera religión o religión verdadera, aunque todavía dentro de ese plan caben innumerables perspectivas, y él nos abrió no pocas de ellas en sus obras posteriores. Únicamente, para no alargarnos, nos detendremos en dos puntos muy importantes, que corresponden a dos de las obras fundamentales del santo: el Libro sobre la Trinidad, y el Libro sobre la Ciudad de Dios.

L. Cilleruelo 